\title{
GUIDE TO MATHEMATICAL MODELLING
}


Consultant Editor: David A. Towers, Senior Lecturer in Mathematics, University of Lancaster

Titles Available:

Guide to Abstract Algebra

Guide to Linear Algebra

Guide to Analysis

Guide to Mathematical Modelling

Guide to Numerical Analysis

Further titles are in preparation 


\section{Guide to Mathematical Modelling}

\section{Dilwyn Edwards and Mike Hamson}

School of Mathematics, Statistics and Computing

Thames Polytechnic, London SE 18 6PF

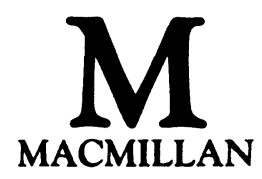


All rights reserved. No reproduction, copy or transmission of this publication may be made without written permission.

No paragraph of this publication may be reproduced, copied or transmitted save with written permission or in accordance with the provisions of the Copyright Act 1956 (as amended), or under the terms of any licence permitting limited copying issued by the Copyright Licensing Agency, 33-4 Alfred Place, London WC1E 7DP.

Any person who does any unauthorised act in relation to this publication may be liable to criminal prosecution and civil claims for damages.

First published 1989

Published by

MACMILLAN EDUCATION LTD

Houndmills, Basingstoke, Hampshire RG21 2XS

and London

Companies and representatives

throughout the world

Typeset by P \& R Typesetters Ltd, Farnham, Surrey, UK

British Library Cataloguing in Publication Data

Edwards, D.

Guide to mathematical modelling.

1. Mathematical models

I. Title II. Hamson, M. J.

$511^{\prime} .8$

ISBN 978-0-333-45935-5

ISBN 978-1-349-10042-2 (eBook)

DOI 10.1007/978-1-349-10042-2 


\section{CONTENTS}

Editor's Foreword

viii

Preface

ix

1 WHAT IS MODELLING?

1.1 Introduction

1.2 Models and modelling

1.3 The learning process for mathematical modelling

1.4 Summary

2 GETTING STARTED

2.1 Introduction

2.2 Examples

2.3 Conclusion

2.4 Further examples

2.5 Further comments on the examples in section 2.2

3 MODELLING METHODOLOGY

3.1 Introduction

3.2 Definitions and terminology

3.3 Methodology and modelling flow chart

3.4 The methodology in practice

3.5 Summary

4 UNITS AND DIMENSIONS 55

4.1 Introduction $\quad 55$

4.2 Units 55

4.3 Dimensions $\quad 60$

4.4 Dimensional analysis $\quad 61$

$\begin{array}{lll}4.5 & \text { Summary } & 65\end{array}$ 
5 MODELLING SKILLS $\quad 67$

$\begin{array}{lll}5.1 & \text { Introduction } & 67\end{array}$

$\begin{array}{lll}5.2 & \text { Listing factors } & 67\end{array}$

$\begin{array}{lll}5.3 & \text { Making assumptions } & 73\end{array}$

$\begin{array}{lll}5.4 & \text { Types of behaviour } & 74\end{array}$

$\begin{array}{lll}5.5 & \text { Translating into mathematics } & 83\end{array}$

$\begin{array}{lll}\text { 5.6 Choosing mathematical functions } & 84\end{array}$

$\begin{array}{lll}5.7 & \text { Relative sizes of terms } & 92\end{array}$

5.8 Reducing the number of parameters 95

$\begin{array}{lll}5.9 & \text { Summary } & 98\end{array}$

6 USING DATA 100

6.1 Introduction 100

$\begin{array}{ll}\text { 6.2 Data collection } & 101\end{array}$

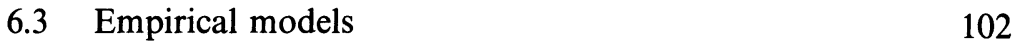

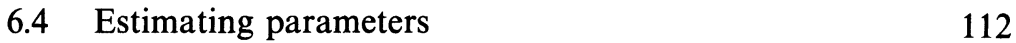

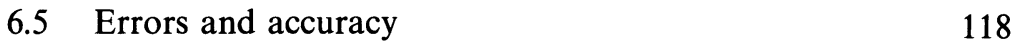

$\begin{array}{ll}6.6 & \text { Testing models } \\ 6.7 & 121\end{array}$

$\begin{array}{lll}6.7 & \text { Summary } & 124\end{array}$

7 USING RANDOM NUMBERS

$\begin{array}{lll}7.1 \text { Introduction } & 125\end{array}$

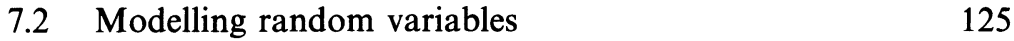

$\begin{array}{lll}7.3 & \text { Generating random numbers } & 130\end{array}$

$\begin{array}{lll}7.4 & \text { Simulations } & 134\end{array}$

$\begin{array}{lll}7.5 & \text { Using simulation models } & 144\end{array}$

7.6 Packages and simulation languages 149

$\begin{array}{lll}7.7 & \text { Summary } & 149\end{array}$

8 USING DIFFERENTIAL EQUATIONS

8.1 Introduction 151

8.2 First order, one variable 152

$\begin{array}{ll}\text { 8.3 Second order, one variable } & 157\end{array}$

8.4 Second order, two variables (uncoupled) 171

$\begin{array}{lll}\text { 8.5 Simultaneous coupled differential equations } & 177\end{array}$

$\begin{array}{lll}8.6 & \text { Summary } & 188\end{array}$

9 REPORT WRITING AND PRESENTATIONS 190

$\begin{array}{lll}9.1 \text { Introduction } & 190\end{array}$

$\begin{array}{lll}9.2 & \text { Report writing } & 190\end{array}$

$\begin{array}{lll}9.3 & \text { A specimen report } & 196\end{array}$

$\begin{array}{lll}9.4 & \text { Presentation } & 209\end{array}$ 
10 EXAMPLE MODELS

212

10.1 Introduction 212

10.2 Doing the dishes 212

10.3 Shopping trips 218

10.4 Disk pressing 222

10.5 Gutter 227

10.6 Turf 233

10.7 Parachute jump 237

10.8 On the buses 244

10.9 Further battles 249

10.10 Snooker 253

10.11 Further models 259

$\begin{array}{ll}\text { Bibliography } & 268\end{array}$

Solutions to Exercises $\quad 269$

$\begin{array}{ll}\text { Index } & 275\end{array}$ 


\section{EDITOR'S FOREWORD}

Wide concern has been expressed in tertiary education about the difficulties experienced by students during their first year of an undergraduate course containing a substantial component of mathematics. These difficulties have a number of underlying causes, including the change of emphasis from an algorithmic approach at school to a more rigorous and abstract approach in undergraduate studies, the greater expectation of independent study, and the increased pace at which material is presented. The books in this series are intended to be sensitive to these problems.

Each book is a carefully selected, short, introductory text on a key area of the first-year syllabus; the areas are complementary and largely selfcontained. Throughout, the pace of development is gentle, sympathetic and carefully motivated. Clear and detailed explanations are provided, and important concepts and results are stressed.

As mathematics is a practical subject which is best learned by doing it, rather than by watching or reading about someone else doing it, a particular effort has been made to include a plentiful supply of worked examples, together with appropriate exercises, ranging in difficulty from the straightforward to the challenging.

When one goes fellwalking, the most breathtaking views require some expenditure of effort in order to gain access to them; nevertheless, the peak is more likely to be reached if a gentle and interesting route is chosen. The mathematical peaks attainable in these books are every bit as exhilarating, the paths are as gentle as we could find, and the interest and expectation are maintained throughout to prevent the spirits from flagging on the journey.

Lancaster, 1988

David A. Towers

Consultant Editor 


\section{PREFACE}

Whilst there are a number of recent texts in mathematical modelling of the 'case study' variety, these are generally of most use as source material for the teacher. This Guide to Mathematical Modelling, however, is intended to be read by students; so the topics treated and the order of contents have been chosen with this in mind. We have tried to address the problem of how mathematical modelling is done as well as what a mathematical model is, and so have avoided presenting just a long catalogue of completed modelling examples.

The book is essentially a first course; so the amount of prerequisite mathematics and statistics is quite modest. It is chiefly aimed at the first-year level in an undergraduate degree course in mathematical sciences, but the treatment is such that the book could be used in the second year of a school sixth form. The contents have formed the basis of the first-year modelling course for students studying for B.Sc. in Mathematics, Statistics and Computing at Thames Polytechnic and have proved a successful component in this course. The book stops short of investigating large-scale simulation models requiring software packages, but it lays valuable groundwork for subsequent study of such models.

At the outset, it is important to explain not only what modelling is, but also why it is worth doing. It is not merely a means of making the usual first-year curriculum in mathematics and statistics more lively and applicable. To accept that is to miss the point. The objective is to provide an approach to formulating and tackling problems in terms of mathematics and statistics. Eventually, when entering employment where real problems have to be dealt with, mathematicians will require additional skills to those fostered by study of conventional topics on the curriculum. The study of modelling promotes the development of these extra skills.

The book is divided into 10 chapters. Although it is not necessary to read the book strictly in chapter order, this may be preferred since there is some progression in difficulty as the subject is developed. It is vital, however, that readers try their hand at solving many of the problems posed, since modelling skills can only be learned by active participation. 
Having set the scene in the opening chapter, some simple modelling problems are presented in chapter 2. These come from a variety of backgrounds, and readers should try some of the examples themselves from the problem descriptions provided. Mathematical modelling is by its nature difficult to structure, but it is useful to lay down general guidelines within which to operate when faced with new situations. To this end a general methodology is described in chapter 3.

The succeeding three chapters are particularly important for the beginner. Here the essential skills for successful modelling are developed. These are as follows.

1 Identifying the problem variables.

2 Constructing appropriate relations between these variables.

3 Taking measurements and judging the size of quantities.

4 Collecting data and deciding how to use them.

5 Estimating the values of parameters within the model that cannot be measured or calculated from data.

The backbone of the text comes in chapters 7 and 8 . Chapter 7 deals with approaches to problems involving random features which demand some statistical analysis. Chapter 8 covers modelling situations which give rise to differential equations, such as are often encountered in physics and engineering.

Communication is vital for successful implementation of a mathematical model. It is necessary to explain ideas behind a model to other people, some of whom may not necessarily hold the same opinion as the modeller. It is also necessary to advise on the use of a model, often to non-specialists who need only to understand the essential points. Further, both at college and later in employment, it is often necessary to present findings verbally to a small group. These communication skills do not always come naturally; so, in chapter 9 , advice is given on these matters.

Finally, in chapter 10, more demanding modelling assignments are presented. Some of the models are fully developed but others are left for the reader to process.

The content of this book complements other material usually studied in a mathematics degree course, and there is plenty of scope for further work in modelling as experience in mathematics and statistics is increased. Solving real problems by mathematical modelling is a challenging task, but it is also highly rewarding. If by working through the book readers gain confidence to take up this challenge, then the authors will be satisfied that the effort of writing the book has been worthwhile. 